\title{
Morphometric analysis of intimal thickening secondary to stent placement in pig carotid arteries ${ }^{1}$
}

\author{
Análise morfométrica do espessamento intimal secundário ao implante de stent em \\ artérias carótidas de suínos
}

\author{
Márcio Bastiani Pasa ${ }^{\text {, Adamastor Humberto Pereira }}{ }^{\text {II }}$, Cyro Castro Júnior ${ }^{\text {II }}$ \\ ${ }^{\mathrm{I}}$ Master in Surgery, Post-Graduate Program, Medicine School, Rio Grande do Sul Federal University (UFRGS). Vascular and Endovascular \\ Surgery, Lutheran University of Brazil (ULBRA), Canoas, Brazil. \\ II PhD, Head of the Vascular Surgery Service, Clinics Hospital, Porto Alegre. Associate Professor, Surgery Department, Medicine School, \\ UFRGS, Porto Alegre, Brazil. \\ III Master in Surgery, Post-Graduate Program, Medicine School, UFRGS, Porto Alegre, Brazil.
}

\begin{abstract}
Objective: To evaluate intimal thickening secondary to stent placement or to insertion of the delivery system without stent placement in pig carotid arteries. Methods: Stents were placed in the right common carotid arteries of 7 pigs, and 7 other control pigs underwent only insertion of the delivery system without stent placement. Uninjured contralateral common carotid arteries of the two groups were also used as controls. Samples of arterial tissue, obtained from the area adjacent to the distal segment of the stent four weeks after placement, underwent morphometric analysis. Morphometric data were compared with findings for arterial samples from injured arteries of the control group and uninjured contralateral arteries of the two groups. The unpaired Mann-Whitney $U$ test and the Wilcoxon $t$ test for nonparametric samples were used for statistical analysis. Results: Greater intimal thickening was found in the group in which stents were placed ( $\mathrm{p}=0.008)$. Changes in luminal area and media layer were not significantly different between the two groups. The comparison of contralateral carotid arteries of the two groups revealed significant changes in intimal and luminal areas. No statistically significant changes were found in medial layer area. Conclusions: All arteries that underwent stent placement showed intimal thickening without changes in the tunica media at four weeks. Dissection and insertion of the delivery system without stent placement was associated with a lesser degree of intimal thickening.
\end{abstract}

Key words: Stents. Constriction, Pathologic. Vascular Diseases. Animal Experimentation.

\section{RESUMO}

Objetivo: analisar o espessamento intimal adjacente ao implante de um stent em artérias carótidas de suínos e aquele secundário à simples manipulação da artéria pelo introdutor do dispositivo. Métodos: sete suínos receberam o implante de um stent na artéria carótida comum direita, sob dissecção direta do vaso e sete animais controles sofreram manipulação arterial, com o sistema introdutor, sem o implante do stent. As artérias carótidas comuns contralaterais não lesadas, dos dois grupos, também foram utilizadas como controle. Realizada a análise morfométrica de amostras de tecido arterial, obtidas junto ao segmento distal do stent, quatro semanas após o implante. Os achados morfométricos foram comparados com amostras arteriais oriundas das carótidas lesadas, no grupo controle, e das carótidas contralaterais não lesadas dos dois grupos. A análise estatística foi realizada através do teste de Mann-Whitney e do teste T de Wilcoxon, para amostras não-paramétricas $(\mathrm{p}<0,05)$. Resultados: observado um maior espessamento intimal no grupo submetido ao implante de stent $(\mathrm{p}=0,008)$. As áreas luminais e da camada média não apresentaram alterações significativas, entre os dois grupos. Quando os dois grupos foram comparados às suas respectivas artérias carótidas contralaterais, foram encontradas alterações significativas nas mensurações da área intimal e do lúmen arterial. Não houve alterações estatisticamente significativas na área da camada média. Conclusões: todas as artérias submetidas ao implante do stent apresentaram espessamento intimal, sem alterações na camada média, quatro semanas após o implante de um stent. A simples manipulação arterial provocou espessamento intimal.

Descritores: Contenedores. Constrição Patológica. Doenças Vasculares. Experimentação Animal.

1. Research performed at the Pos-Graduate Program of Surgery, Medicine School, Rio Grande do Sul Federal University (UFRGS), Porto Alegre, Brazil. 


\section{Introduction}

Atherosclerosis is the major cause of death in developed countries and greatly responsible for the pathogenesis of strokes, myocardial infarctions, gangrene and loss of limb function ${ }^{1}$.

A drastic revolution in the treatment of atherosclerotic disease has occurred, first with the development of catheters for transluminal dilatation, then with balloon dilatation angioplasty, and recently with the introduction of intraluminal stents and endovascular prostheses $^{2}$.

Studies about interventions to treat atherosclerotic lesions, such as balloon or laser angioplasty, atherectomy, endoprostheses and bypasses, show that patency is reduced in the middle and long term due to recurrence of lesions, a phenomenon called restenosis ${ }^{3}$.

Stent placement is the only intervention that significantly reduces the occurrence of restenosis.

The purposes of this study were to measure arterial wall intimal thickening secondary to stent placement and to investigate whether arterial dissection and delivery system insertion caused any degree of hyperplasia.

\section{Methods}

Fourteen healthy mixed-breed (Landrace $\mathrm{x}$ Large White) pigs with a mean weight of $30 \mathrm{~kg}$ were used in the experiment. This study was approved by the Ethics Committees of the Research and Graduate Studies Group (GPPG) of Hospital de Clinicas de Porto Alegre, Universidade Federal do Rio Grande do Sul (UFRGS), and reviewed by the Board of Directors of the Veterinary Hospital (UFRGS). Another group of 7 pigs was used in a previous pilot study to test the experimental methodology.

The stents used were 3-cm-long 316L-steel Z stents with a final diameter of $3.8 \mathrm{~mm}$, manufactured by the Laboratory of Mechanics (Laboratório de Transformação Mecânica) of the School of Engineering, UFRGS.

Surgical procedures were conducted with the animals under general anesthesia delivered by inhalation using a non-rebreathing open system. The animals were fasted for 6 hours, weighed and administered $10 \mathrm{mg}$ IM midazolam and $1 \mathrm{~g}$ IV cephalothin before the surgical procedure. Anesthesia was induced with $2.5 \%$ IV thiopental sodium, and the animals were ventilated with oxygen masks and room air. Anesthesia was maintained with halothane, and the animals were administered a glucose-saline solution to replace fluid losses.

The study was divided into two phases, and the animals were randomly divided into two groups of seven animals: STENT group and NO STENT group.

\section{Phase 1}

- $\quad$ Right anterolateral cervicotomy to approach the right common artery (RCA), transoperative collection of venous blood for blood (hematocrit, hemoglobin and leukocytes) and serum (total cholesterol, fractions and triglycerides) tests, systemic heparinization (100 $\mathrm{UI} / \mathrm{kg}$ ), and chemical dilatation of artery by external application of papaverine hydrochloride to the vessel;

- Interruption of carotid blood flow with bulldog clamps.

- Cranial insertion of delivery system containing the stent and, in the STENT group, deployment of stent with the proximal arm placed at about $2 \mathrm{~cm}$ from the puncture site; in the NO STENT group, simple insertion of the delivery system to about $5 \mathrm{~cm}$ with no stent deployment.

- Removal of the delivery system.

- Selective arteriography after direct puncture of the artery and direct injection of $1 \mathrm{ml} / \mathrm{kg}$ iothalamate meglumine using a portable $\mathrm{X}$-ray unit and developed on X-ray film.

- Tissue planes closed with 2-0 monofilament nylon suture.

- Animals were housed in stalls with running water and were fed their usual diet adjusted to age.

\section{Phase 2}

- After 4 weeks, the preoperative procedures, anesthesia, surgical approach and venous blood collection were repeated; the animals were administered heparin $(100 \mathrm{Ul} / \mathrm{kg}$ ) for systemic anticoagulation and $20 \mathrm{mg}$ papaverine hydrochloride for vessel dilatation.

- Arteriography was performed following the same procedures as in the first phase.

- $\quad$ After the patency of vessels was confirmed by arteriography, the right (RCC) and left (LCC) common carotid arteries were removed and their ends were ligated.

- Surgical specimens were irrigated with $0.9 \%$ saline solution, fixed in $10 \%$ formalin, and kept under 100 $\mathrm{mmHg}$ pressure for 15 minutes.

- The animals were sacrificed; the guidelines for the use of animals established by Brazilian Law 6638 issued on May 8, 1979, were followed all through the experiment. Skin suture was removed 10 days after the initial procedure.

For microscopic analysis, 0.3-cm-long transverse sections of arterial segments were obtained from the distal margin of the RCC artery, and the metal struts were carefully removed (STENT group); from a point $4 \mathrm{~cm}$ beyond the arteriography site (NO STENT group); and from a point in the middle segment, $4 \mathrm{~cm}$ from the bifurcation (control group). The specimens in these three groups were embedded in paraffin; 4- $\mu \mathrm{m}$ thick sections were mounted on histologic slides and stained using the Verhoeff and hematoxylin-eosin (HE) techniques.

The images of histologic sections were captured and digitalized using a conventional light microscope with a phototube, a color video camera, and an analog-digital conversion board (Image ProPlus Capture Kit, Media Cybernetics, USA), which generated 640x480 pixel, 24-bit image files that were stored in a computer at a $20 \mathrm{x}$ magnification for morphometric analysis. The Image ProPlus 4.1 (Media Cybernetics, USA) and Image (Scion 
Corporation, USA) software packages were used for morphometry and image analysis. Planimetry for the calculation of areas of lumen, intimal layer, and medial arterial layer was conducted automatically without the interference of the observer.

For each specimen, the luminal area was obtained by direct measurement of the area outlined by the endothelium; the intimal area was calculated by subtracting the luminal area from the area outlined by the internal elastic lamina (IEL); finally, the area of the medial layer was the result of the subtraction of the luminal and intimal areas from the area outlined by the external elastic lamina (EEL) ${ }^{4-}$ ${ }^{8}$. The morphometric value for each arterial layer was calculated as the mean value of eight circumferential measurements 9 .

Exclusion criteria were death of the animal before tissue collection, trans- and postoperative surgical complications, and technical failures in the preparation and processing of specimens.

The SPSS for Windows 8.0 (MICROSOFT $^{\circledR}$, USA) software was used for data analysis. Parametric variables were described as means and standard deviations, and nonparametric variables, as medians and interquartile ranges (25-75 percentiles). Continuous variables were evaluated according to their distribution, and the most adequate statistical test was then chosen.

The variable "weight" was compared between groups using the Student $t$ test for independent samples and between the two phases of the study using the Student $t$ test for paired samples. The variable "sex" was analyzed using the Fisher exact test. The analysis of blood and serum variables was conducted with the Student $t$ test for paired samples. As the morphometric analysis included nonnormally distributed continuous variables, the nonparametric Mann-Whitney test for independent samples was used for the comparisons between the STENT and the NO STENT groups, and the nonparametric Wilcoxon $t$ test for paired samples for the comparisons between the RCC and LCC of each animal. The level of significance was set at $5 \%(\mathrm{p}<0.05)$.

\section{Results}

No animal was excluded from the study. The evaluation of arteriograms at the two study phases showed that all arteries that underwent stent placement and all that underwent only delivery system insertion were patent.

The analysis of weight and sex in the first study phase did not reveal any statistically significant differences between the 14 animals. Weight increases between the two phases of the study were statistically significant.

\section{Lipid profiles}

The analysis of lipid profiles and blood tests of samples collected during the two interventions did not reveal any statistically significant differences.

Morphometric analysis of arterial wall

The morphometric analysis of the arterial wall was conducted by comparing the STENT and NO STENT groups and, within each group, the RCC artery, which underwent one of the procedures, and the LCC artery, which was not injured.

In general, the analysis of the relations between the areas of the intimal and medial layers, as well as between luminal area and animal weight showed the same trend of variation as the area measurements.

\section{Comparison between STENT and NO STENT groups}

The morphometric analysis comparing the areas of the arterial layers between the STENT and NO STENT groups revealed a statistically significant difference only between the intimal areas: $0.1689 \mathrm{~mm}^{2}(0.1224-0.3979)$ in the STENT group and $0.0021 \mathrm{~mm}^{2}(0.0014-0.0038)$ in the NO STENT group $(\mathrm{p}=0.008)$. The analysis of luminal and medial areas did not reveal any significant differences. The intimal index was significantly different, and was 2.8679 (2.3989$3.8422)$ in the STENT group, and $0.0454(0.0310-0.0842)$ in the NO STENT group $(\mathrm{p}=0.001)$.

TABLE 1 - Morphometric analysis of areas in the STENT and NO STENT groups

\begin{tabular}{|c|c|c|c|}
\hline Variable & $\operatorname{STENT}(\mathrm{n}=7)$ & NO STENT(n=7) & $\mathrm{p}$ \\
\hline Luminal area $\left(\mathrm{mm}^{2}\right)$ & $6.8812(3.0201-8.0400)$ & $3.5980(2.6660-5.2890)$ & 0.179 \\
\hline Intimal Area $\left(\mathrm{mm}^{2}\right)$ & $0.1689(0.1224-0.3979)$ & $0.0021(0.0014-0.0038)$ & $0.008^{*}$ \\
\hline Medial Area $\left(\mathrm{mm}^{2}\right)$ & $6.4890(5.1023-8.8180)$ & $4.9720(4.5125-5.2190)$ & 0.141 \\
\hline Intimal Index & $2.8679(2.3989-3.8422)$ & $0.0454(0.0310-0.0842)$ & $0.001 *$ \\
\hline
\end{tabular}


The morphometric analysis comparing the areas of the different RCC artery layers in each animal in the STENT group, and the matching uninjured LCC artery, did not reveal any statistically significant differences: The luminal area was $6.8812 \mathrm{~mm} 2(3.0201-8.0400)$ in the right side and $15.6323 \mathrm{~mm} 2(14.8350-17.0960)$ in the left side $(\mathrm{p}=0.018)$; the intimal area ranged from $0.1689 \mathrm{~mm} 2(0.1224$ -
$0.3979)$ in the right side to $0.0014 \mathrm{~mm} 2(0.0011-0.0018)$ in the left side $(\mathrm{p}=0.018)$ The differences between the areas of the medial layer were not significant. The intimal index was significantly different, and ranged from 2.8679 (2.3989$3.8422)$ in the right side to $0.0302(0.0208-0.0361)$ in the left side $(\mathrm{p}=0.018)$.

TABLE 2 - Morphometric analysis of areas in the STENT group

\begin{tabular}{llll}
\hline Variable & STENT - RCC & CONTROL_LCC & $\mathrm{p}$ \\
Luminal area $\left(\mathrm{mm}^{2}\right)$ & $6.8812(3.0201-8.0400)$ & $15.6323(14.8350-17.0960)$ & $0.018^{*}$ \\
Intimal Area $\left(\mathrm{mm}^{2}\right)$ & $0.1689(0.1224-0.3979)$ & $0.0014(0.0011-0.0018)$ & $0.018^{*}$ \\
Medial Area $\left(\mathrm{mm}^{2}\right)$ & $6.4890(5.1023-8.8180)$ & $4.9820(4.6325-5.3020)$ & 0.063 \\
Intimal Index & $2.8679(2.3989-3.8422)$ & $0.0302(0.0208-0.0361)$ & $0.018^{*}$ \\
\hline
\end{tabular}

Wilcoxon $t$ test $(\mathrm{p}<0.05)$. Values: medians and interquartile ranges $(26-75$ percentiles). $\mathrm{N}=$ number of animals per group; RCC and LCC. Right and left common carotid artery. * statistically significant.

The morphometric analysis comparing the areas of the different RCC artery layers in each animal in the NO STENT group, and the matching uninjured LCC artery, revealed statistically significant differences: The luminal area ranged from $3.5980 \mathrm{~mm}^{2}(2.6660-5.2890)$ in the right side to $13.5620 \mathrm{~mm}^{2}(7.0320-17.3210)$ in the left side $(\mathrm{p}=0.018)$; the intimal area was $0.0021 \mathrm{~mm}^{2}(0.0014-0.0038)$ in the right side, and $0.0016 \mathrm{~mm}^{2}(0.0013-0.0026)$ in the left side $(\mathrm{p}=0.018)$. The differences between the areas of medial layers were not significant. The intimal index was significantly different: it was $0.0454(0.0310-0.0842)$ in the right side, and $0.0273(0.0237-0.0646)$ in the left side $(\mathrm{p}=0.018)$.

TABLE 3 - Morphometric analysis of areas in the NO STENT group

\begin{tabular}{|c|c|c|c|}
\hline Variable & NO STENT - RCC & CONTROL-LCC & $\mathrm{p}$ \\
\hline Luminal area $\left(\mathrm{mm}^{2}\right)$ & $3.5980(2.6660-5.2890)$ & $13.5620(7.032-17.3210)$ & $0.018^{*}$ \\
\hline Intimal Area $\left(\mathrm{mm}^{2}\right)$ & $0.0021(0.0014-0.0038)$ & $0.0016(0.0013-0.0026)$ & $0.018 *$ \\
\hline Medial Area $\left(\mathrm{mm}^{2}\right)$ & $4.9720(4.5125-5.2190)$ & $5.4002(4.2090-5.8602)$ & 0.499 \\
\hline Intimal Index & $0.0454(0.0310-0.0842)$ & $0.0273(0.0237-0.0646)$ & $0.018 *$ \\
\hline
\end{tabular}




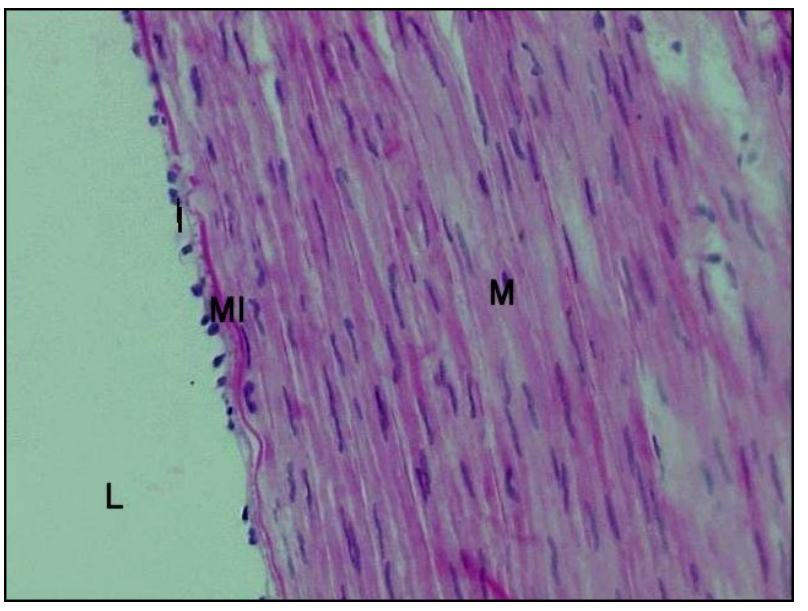

FIGURE 1 - Photomicrograph of normal uninjured LCC artery of a pig. Staining: HE. Original magnification: 100x. Thin intimal layer outlined by IEL. L: Vessel lumen; I: Intimal layer; M: Medial layer; MI: IEL

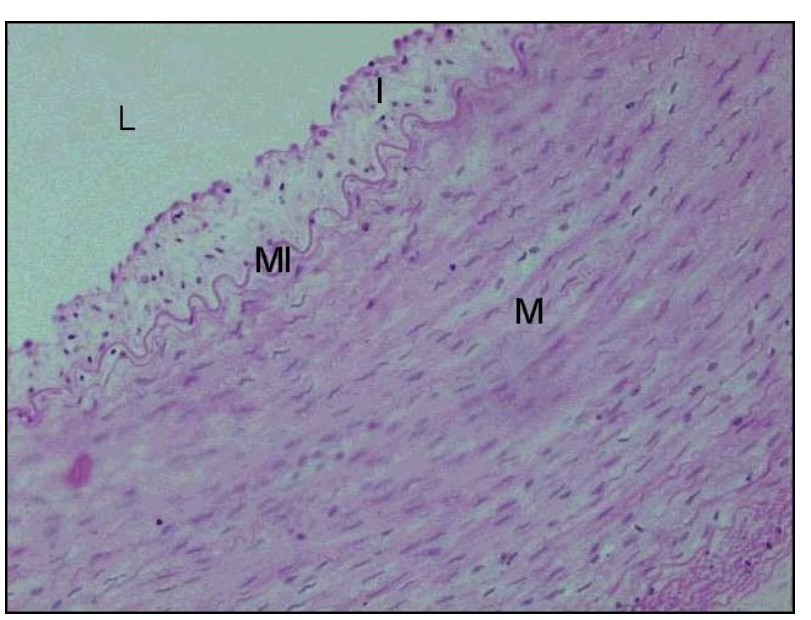

FIGURE 2 - Photomicrograph of RCC artery of NO STENT group 4 weeks after injury. Staining: HE. Original magnification: 100x. IEL clearly outlines thickened intimal layer of medial layer. I: Intimal layer; L: Vessel lumen; M: Medial layer; MI: IEL

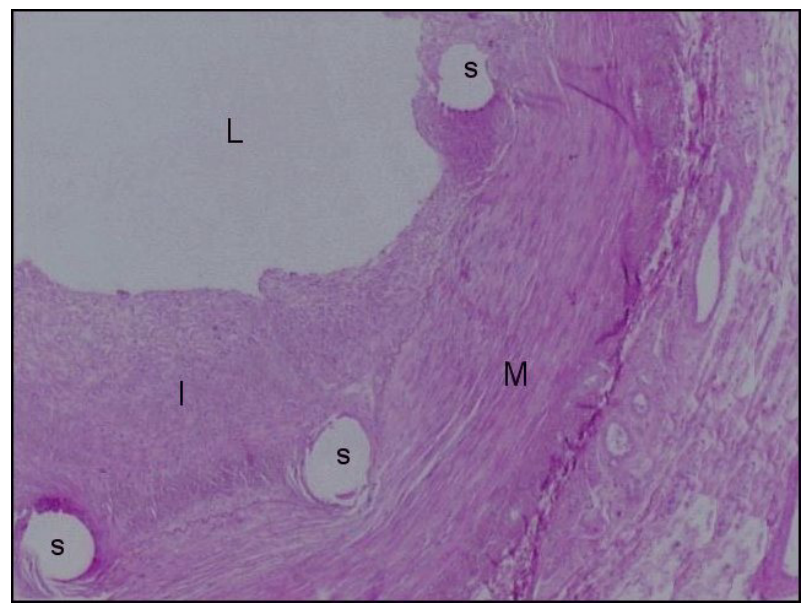

FIGURE 3 - Photomicrograph of RCC artery of STENT group 4 weeks after stent placement. Staining: HE. Original magnification: 100x. Intense intimal thickening seen in sites of three metal stent fragments. I: Intimal layer; L: Vessel lumen; M: Medial layer; S: Sites of metal stent fragments (removed)

\section{Discussion}

Of the several models to evaluate intimal hyperplasia, only a few have demonstrated a correlation in clinical trials ${ }^{5,10}$. Ideally, specimens should be the same size and have the same histologic and biochemical structure as those obtained form human arteries. Numerous authors have used pigs in their studies because small animals are not believed to be good models, as their response to injury significantly differs from human responses.

Carotid arteries have been used in several morphometric studies ${ }^{5,12,15,16}$. In this study, the common carotid artery was chosen because of its high blood flow and easy access through dissection.

The induction of intimal hyperplasia by means of injury to a nonsclerotic vessel may be controversial, but is supported by authors such as Muller et al. ${ }^{17}$, who see it as an alternative to obtain a controlled chronic arterial lesion. Other authors also used normal arteries for the morphometric analysis of arteries that underwent stent placement ${ }^{18,19}$.

Response to vascular injury has been controlled in several ways s, $^{5,8,20,21}$. In this study, the contralateral carotid arteries were not injured with the delivery system because such procedure might have led to changes in carotid blood flow. Another group of animals was used as control: their carotid arteries underwent dissection and insertion of the delivery system but no stent placement.

Self-expandable stents were used because the purpose of this study was to evaluate the isolated chronic reaction to the stent as a foreign body on the arterial wall, and not the reaction to angioplasty injury, which has already been extensively studied. Therefore, this study evaluated only the role of the stent in the induction of 
hyperplasia. In the control group, injuries were also produced without vessel angioplasty to evaluate whether injuries alone had any role in intimal thickening. Previous angioplasty or balloon-expanded stents were not used because these procedures may lead to marked intimal hyperplasia. They induce a more extensive lesion of the tunica media, and if used in this study, they would be likely to affect results.

Pigs raised in pastures develop atherosclerotic lesions in four to eight years. In contrast, pigs fed diets rich in cholesterol show rapid changes in lipid profiles, similarly to what happens to human beings ${ }^{17}$. In this study, a diet without lipid supplementation was used to avoid the risk of hypercholesterolemia. The comparison of lipid profiles in the two phases of the study did not reveal any statistically significant differences, which indicates that there was no interference in the natural progression of intimal proliferation.

Blood viscosity directly affects blood flow and, consequently, intimal hyperplasia. The role of changes in platelet and leukocyte counts in the genesis of intimal hyperplasia is well known. ${ }^{22}$ In this study, leukocyte, platelet and erythrocyte counts were monitored, but significant changes, which might have affected intimal hyperplasia, were not found.

Steele et al. ${ }^{15}$ evaluated response to injury in carotid arteries of pigs that underwent angioplasty. They found that, during the first week, there was a progressive decrease in platelet deposition, initial regrowth of endothelium, progressive migration and proliferation of smooth muscle cells, and neointimal formation. Intimal hyperplasia was significantly greater and more uniform at 14 days, and tended to stabilize after 30 or 60 days. Several studies used four weeks as the cut-off point for the analysis of changes in arterial walls ${ }^{8,11,18-20,23}$. Based on those studies, the interval between the first and second phases of this study was four weeks, which should be enough for the confirmation of intimal thickening secondary to stent placement.

Morphometry was performed using the arterial segment immediately distal to the stent because it was in a segment of the carotid artery that was not injured by dissection or delivery system insertion. Intimal hyperplasia secondary to stent placement occurs primarily around each of the stent arms, and can be, therefore, measured in the region adjacent to the stent edge ${ }^{24}$.

The comparison of the STENT and NO STENT groups to each other revealed a statistically significant difference in measurements of the area of the intimal layer and its relation to the medial layer (intimal index), as well as the relation between intimal area and animal weight. No significant differences were found in the comparisons of luminal or medial layer areas, nor in the relation of these areas to animal weight.

The comparison of morphometric data for each group with findings for the matching contralateral normal carotid arteries showed statistically significant changes in the intimal layer (intimal area and intimal index) in the two groups. Similarly, significant changes were found in luminal areas of each group when compared with their normal controls.

Changes in medial layer areas were not significant when compared between groups or with the contralateral normal controls.

The fact that significant intimal hyperplasia was found in the NO STENT group demonstrates that the simple insertion of the delivery system in the arterial lumen and the circumferential vessel dissection are sufficient to cause some degree of intimal injury and consequent hyperplasia, which was, however, less intense than the one found in the STENT group.

Edelman and Rogers ${ }^{24}$ also found that stent placement without previous dilatation reduces endothelial damage and intimal hyperplasia. Similarly, Schürmann et al. ${ }^{9}$ found that self-expandable $\mathrm{Z}$ stents produce less arterial injury, which results in a lower degree of intimal hyperplasia. Laird et al. ${ }^{11}$ studied pigs with stents placed in normal arteries without previous dilatation, as the pigs in the STENT group in our study. They assigned the low degree of intimal hyperplasia to the fact that the internal elastic membrane was uninjured.

Absolute luminal area was greater in the STENT than in the NO STENT group, but the difference was not statistically significant. The use of stents seems to eliminate elastic recoil and thus reduce the effect of arterial remodeling on the decrease of luminal area and stenosis.

The luminal area of the RCC arteries (dissected) was significantly smaller than that of the LCC arteries (not dissected). The injury caused by the delivery system insertion was probably responsible for such reduction of the luminal area due to arterial remodeling. Post et al. ${ }^{14}$ also found that the adventitious layer had some effect on arterial remodeling.

In summary, significant intimal hyperplasia occurred after stent placement even when previous or concurrent artery dilatation was not used. These findings are important in the study of endovascular procedures in which a sum of factors contributes to response to lesion. More sophisticate techniques should be investigated, and the indication of stent placement should always be carefully decided.

Materials to manufacture stents, less injurious shapes and techniques, and pharmacologic or genetic therapies as adjuvant treatments seem to be areas of study that should be further investigated to improve the clinical results of endovascular surgery.

\section{Conclusion}

The placement of endoluminal prostheses, or stents, in normal common carotid arteries of pigs produced, after four weeks, a chronic inflammatory reaction of the arterial wall adjacent to the stent, with greater intimal thickening than that observed in vessels injured only by delivery system insertion but not stent placement. 


\section{References}

1. Ross, R. The pathogenesis of atherosclerosis: a perspective for the 1990s. Nature.1993; 362: 801-9.

2. Coward LJ, Featherstone RL, Brown MM. Percutaneous transluminal angioplasty and stenting for carotid artery stenosis. Cochrane Database Syst Rev. 2004; (2): CD000515.

3. Dominik JH, Anthony C, Pereira MD, Andrew CFRCR, J. Martin B, Martin MB, on behalf of the CAVATAS Investigators. Restenosis after carotid angioplasty, stenting, or endarterectomy in the carotid and vertebral artery transluminal angioplasty study (CAVATAS). 2005 feb; 36(2): 2816.

4. Angelini GD, Bryan AJ, Williams HMJ, Soyombo AA, Williams A, Tovey J, Newby AC. Time course of medial and intimal thickening in pig venous arterial grafts: Relationship to endothelial injury and cholesterol accumulation. J Thorac Cardiovasc Surg. 1992;103:1093-103.

5. Caramori PRA, Eggers EE, Silva-Filho APF, Uchoa DM, Jung F, Zago AC, Cerski CTS, Schawartsmann G, Zago AJ. Postangioplasty restenosis: a practical model in the porcine carotid artery. Braz $\mathrm{J}$ Med Biol Res. 1997;30:1087-91.

6. Andersen HR, Maeng M, Thorwest M, Falk E. Remodeling rather than neointimal formation explains luminal narrowing after deep vessel wall injury. Circulation. 1996;93:1716-24.

7. Eggers EE. Influência da interleucina - $1 \beta$ e do fator de necrose tumoral- $\alpha$ na hiperplasia intimal presente em anastomoses enxertos-arteriais com prótese politetrafluoretileno expandido [dissertação]. Universidade de São Paulo; 1998.

8. Castro Jr C, Pereira AH, Pasa MB. Morphometric analysis of the intimal reaction after stent implantation in iliac arteries submitted to angioplasty in pigs. Acta Cir Bras. 2006;21(3):13943.

9. Schürmann K, Vorwerk D, Kulisch A, Kulisch ES, Biesterfeld S, Stopinski T, Günther R. Experimental arterial stent placement: comparison of a new nitinol stent and wallstent. Invest Radiol. 1995;30:412-20.

10. Berger PB, Holmes Jr DR, Ohman M, O'Hanesian MA, Murphy JG, Schwartz RS, Serruys PW, Faxon DP. Restenosis, reocclusion and adverse cardiovascular events after successful balloon angioplasty of occluded versus nonoccluded coronary arteries: results from the multicenter american research trial with cilazapril after angioplasty to prevent transluminal coronary obstruction and stenosis (MARCATOR). J Am Coll Cardiol. 1996;27:1-7.

11. Laird JR, Carter AJ, Kufs, WM, Hoopes TG, Farb A, Nott SH, Fischell RE, Fischell DR, Virmani R, Fishel TA. Inibition of neointimal proliferation with low-dose irradiation from a $\beta$-particle-emitting stent. Circulation. 1996;93:529-36.

12. Link J, Feyerabend B, Grabener M, Linstedt, U, Brosmann J, Thomsem H, Heller M. Dacroncovered stent-grafts for the percutaneous treatment of carotid aneurysms: effectiveness and biocompatibility: experimental study in swine. Radiology. 1996;200:397-401.

13. Lamawansa MD, Wysocki SJ, House AK, Norman PE. Morphometric changes seen in balloon injured porcine iliac arteries: the influence of sympathectomy on intimal hyperplasia and remodelling. Eur J Vasc Endovasc Surg. 1997;13:437.

14. Post MJ, Smet BJGL, Helm YVD, Borst C, Kuntz RE. Arterial remodeling after balloon angioplasty or stenting in na atherosclerotic experimental model. Circulation. 1997;96:996-1003.

15. Steele PM, Cesebro JH, Stanson AW, Holmes Jr DR, Dewanjee MK, Badimon L, Fuster V. Balloon angioplasty: natural history of the pathophysiological response to injury in a pig model. Circ Res. 1985;57:105-12.

16. Byer A, Ussia G, Galleti G. Autologous vein lined and vein covered stents in swine arteries. J Cardiovasc Surg. 1998;39:393-8.

17. Muller DWM, Ellis SG, Topol EJ. Experimental models of coronary artery restenosis. J Am Coll Cardiol. 1992;19:418-32.

18. Karas SP, Gravanis MB, Santoian EC, Robinson K, Andergerg KA, King III SB. Coronary intimal proliferation after balloon injury and stenting in swine: an animal model of restenosis. J Am Coll Cardiol. 1992;20:467-74.

19. Schwartz RS. Pathophysiology of restenosis: interaction of thrombosis, hyperplasia, and/or remodeling. J Am Coll Cardiol. 1998; 81(7A):14E$17 \mathrm{E}$.

20. Grüdtner MA, Pereira AH, Costa LMF, Souza GG, Argenta R, Longhi JA. Efeitos a curto prazo de stents não recobertos e recobertos com politetrafluoroetileno em aorta de suínos: um modelo experimental. Acta Cir Bras. 2004;19(2):1716-24.

21. More RS, Rutty G, Underwood MJ, Brack MJ, Gershlick AH. A time sequence of vessel wall 
changes in an experimental model of angioplasty.

J Pathol. 1994;172:287-92.

22. Chervu A, Moore WS. An overview of intimal hyperplasia. Surgery. 1990;171:433-47.

23. Cragg A, Lund G, Rysavy J, Castaneda F, Zuniga WC, Amplatz K. Nonsurgical placement of arterial endoprostheses: a new technique using nitinol wire. Radiology.1983;147:261-3.

24. Edelman ER, Rogers C. Hoop Dreams: stents without restenosis. Circulation. 1996;94:1199-202.

\section{Correspondence:}

Márcio Bastiani Pasa

Av. Lavras, 599/302 CEP:

90460-040 Porto Alegre-RS Brazil

Phone: (55 51)9961-7061/3333-0003

Fax: (55 51)3227-1321

marciopasa@hotmail.com
Conflict of interest: none Financial source: none

Received: September 04, 2007

Review: November 08, 2007

Accepted: December 10, 2007

\section{How to cite this article}

Pasa MB, Pereira AH, Castro Júnior C. Morphometric analysis of intimal thickening secondary to stent placement in pig carotid arteries. Acta Cir Bras. [serial on the Internet] 2008 Mar-Apr;23(2). Available from URL: http://www.scielo.br/acb 